\title{
Editorial
}

\section{COVID-19 y ética: visión de un psicólogo}

La pandemia de COVID-19 no ha sido la primera epidemia que haya asolado a la humanidad a lo largo de su historia. Probablemente tampoco será la última. Por el contrario, se han registrado muchas que han afectado a millones de personas y dejado innumerables muertos. Entre las más mortales está la llamada "gripa española" de 1918 a 1920, que afectó a millones de personas y causó miles de muertes en Europa y América principalmente, y otras más recientes, como las causadas por el ébola (1976), el H1N1 (2009-2010), el Mers (2012), el Zika (2015-2016), y varias más cuyos efectos se han podido controlar y han sido menos desastrosos.

Lo más grave es que la pandemia causada por el virus SARS-CoV-2 (COVID-19), como lo mencionaba atrás, probablemente no será la última que padezca la humanidad. Como es sabido, los virus conviven con nuestra especie, lo han hecho desde siempre, en muchos casos con consecuencias positivas, en otros, con efectos negativos. Asimismo, en diversas ocasiones se ha documentado la transmisión a partir de una especie animal diferente a la humana. Las transformaciones de un virus pueden tomar mucho tiempo, durante el cual convive con nuestra especie, o ser rápidas y fulminantes con resultados destructivos para el hombre. Al parecer en el caso del SARS-CoV-2, el virus detectado a finales del 2019, uno de los factores desencadenantes pudo ser la destrucción del hábitat de una especie (posiblemente un tipo de murciélago) a causa de la intervención humana.

La sociedad ha desarrollado una gran preocupación por las implicaciones éticas de esta pandemia. Hemos presenciado alrededor del mundo verdaderas catástrofes a nivel sanitario, económico, social y cognitivo, y se ha tratado de entender la situación desde una perspectiva basada en la ética humanista, en el respeto por los derechos humanos, por el bienestar de las personas y por la naturaleza.

En muchos países se han creado consejos nacionales de bioética para enfrentar los problemas asociados con la COVID-19, y la UNESCO, por su parte, emitió el 6 de abril de 2020 la "Declaración sobre el COVID-19: consideraciones éticas desde una perspectiva global", en la cual se destacan aspectos fundamentales como la necesidad de, 1) brindar información precisa, clara, completa y transparente a los periodistas, los científicos y el público en general sobre la COVID-19, sus orígenes, desarrollo, perspectivas de curación, vacunas, y las soluciones posibles a las crisis de salud, económicas, sociales y otras; 2) dar a conocer a nivel internacional los resultados de las investigaciones científicas que se llevan a cabo a nivel local, y 3 ) formar comités de investigación responsables de centralizar la información científica y compartirla a nivel mundial.

En el caso específico de las empresas y grupos dedicados a la investigación y la producción de conocimientos y de tecnologías de prevención, promoción y curación, como las universidades, los institutos de salud y las compañías farmacéuticas, se han enfatizado cuatro pilares: el respeto, la honestidad, la rectitud y el cuidado. Estos serían los fundamentos de una nueva ética, una ética humanista y de cuidado que nos lleve a considerar, como se ha afirmado, que nos salvamos todos o no se salva nadie.

Hemos entendido que el ser humano no está aislado, y que necesitamos unos de otros, lo que se hace evidente cuando se reflexiona acerca de problemas tales como las desigualdades en el acceso a la atención de salud, a las vacunas y a la educación sanitaria, desigualdades que se han hecho evidentes en el marco del contagio de la COVID-19 en el número de fallecimientos, la distribución de la información y de las vacunas, y en las actitudes hacia la enfermedad y la manera de enfrentarla. Las sociedades son muy desiguales y esta pandemia puso de manifiesto la falta de equidad y los déficits basados en las clases sociales, los niveles educativos, el acceso a los recursos, y un largo etcétera. 
La vida de la mayor parte de las personas tuvo que modificarse después del 2 de marzo del 2020 cuando la Organización Mundial de la Salud (OMS) sentenció que estábamos en una pandemia de proporciones planetarias. Las ciudades decretaron cuarentenas, el trabajo cambió notablemente, y la educación pasó a ser virtual (o mixta) en todos los niveles, desde el preescolar hasta el universitario. Las relaciones familiares sufrieron tropiezos causados por el confinamiento, el trabajo en casa, la necesidad de pasar todo el día y todos los días (24/7) en espacios reducidos. En algunos casos este confinamiento sirvió para unificar a las familias, mostrar que los padres son maestros, pero en otros casos el resultado fue el opuesto, aumentó la violencia familiar, la depresión, el estrés, y salieron a flote problemas psicológicos que estaban latentes y que en ese ambiente se hicieron manifiestos.

Todo ello se vio acentuado por el aumento del desempleo, la desnutrición infantil y el malestar social. El consumo de bebidas alcohólicas y de sustancias psicotrópicas, así como otros problemas psicológicos, aumentaron en magnitud y se hicieron más visibles.

Por otra parte, además de los conflictos económicos, sociales y de salud, la incapacidad de muchas instituciones para hacer frente a la pandemia llevó a que la gente perdiera la fe en sus gobiernos y que la perspectiva del futuro se tornara incierta y desesperada.

En ese caldo de cultivo no es extraño que hayan surgido teorías conspirativas -que han existido desde siempre-, pero que se potencian al máximo en períodos de incertidumbre, de malestar, de conflictos cognitivos y de búsqueda de explicaciones a problemas que no hemos sido capaces de explicar y solucionar. Han abundado las noticias falsas (fake news): se ha especulado que la COVID-19 fue creada en un laboratorio de China para debilitar al mundo occidental, o, lo contrario, que se hizo en un laboratorio de Estados Unidos para acabar con China. La negación de la existencia misma de la enfermedad, los movimientos anti-vacuna, ahora más visibles que nunca antes, la creencia en "chips" que, absurdamente, se instalarían en el organismo con las vacunas, la creencia de que su producción está sujeta a una rebatiña económica, y muchas otras teorías tan absurdas como estas, son consideradas válidas y acogidas por cientos de miles de personas.

Una ética centrada en el ser humano, que permita realizar las potencialidades de los individuos y de las culturas, que se desprenda de la solidaridad y la reciprocidad, características que permitieron que nuestra especie evolucionara de forma adaptativa y produjera sociedades armónicas, es sin duda el camino para enfrentar el reto que hoy estamos viviendo.

\section{Rubén Ardila, Ph.D.}

Psicólogo

Universidad Nacional de Colombia 